\title{
ANALYSIS OF THE EFFECT OF SERVICE QUALITY ON TREATMENT DECISIONS AND PATIENT LOYALTY IN THE OUTPATIENT UNIT OF MAMPANG PRAPATAN HOSPITAL JAKARTA
}

\author{
Cucu Nurgahawan ${ }^{1^{*}}$, Nurminingsih $^{2}$, Dinni Agustin $^{3}$ \\ $1,2,3$ \\ Universitas Respati Indonesia \\ E-mail: ${ }^{1)}$ cucunurgahawan@gmail.com
}

\begin{abstract}
Hospital service quality is the main thing in an effort to improve treatment decisions that will bring patient loyalty. This study aims to analyze the effect of service quality on treatment decisions and patient loyalty in the outpatient unit of Mampang Prapatan Hospital, Jakarta. This study is a quantitative study using SEM analysis to see the relationship between service quality and treatment decisions and patient loyalty. Using a total of 148 respondents with a questionnaire instrument with good validity and reliability values. The direct influence of service quality on patient loyalty resulted in $t$ value $=7,99$ Test the indirect effect of service quality on loyalty through treatment decisions $t$ value $=4,83$. The results of the test of the direct influence of service quality $t=5,64$, the test of the indirect influence of quality on treatment decisions through loyalty $t=5,18$. Therefore, it can be concluded that there is a significant effect of service quality on loyalty directly and indirectly through treatment decisions. Besides that, there is a significant effect of service quality on treatment decisions directly and indirectly through patient loyalty.
\end{abstract}

Keywords: Quality of Service, Treatment Decisions, Patient Loyalty

\section{INTRODUCTION}

Providing high-quality health services while focusing on patient pleasure would allow the company to survive in the face of increasingly fierce global competition, according to its most important competitive strategy (Ristrini, 2005). This has something to do with patient loyalty. Patients' loyalty is influenced by a number of factors, the most important of which are: satisfaction, which is a comparison between expectations before performance and perceived performance; emotional bonding, which can be influenced by a hospital name that has its own appeal, allowing the patient to be identified in a hospital name. One of the qualities of a hospital's name is trust, which refers to a person's desire to entrust the organization or a hospital's name to execute and perform an action. Another attribute is reduction in options (choice reduction). Patients will feel more comfortable with a hospital's name when making transactions since it has become a habit (ease). Patients' history with the company (experience of the firm), specifically the patient experience of the company, can help to shape their behavior in the future (Kotler \& Armstrong, 2001). Patients who are satisfied with their treatment are more likely to return, and all of those who return develop a sense of loyalty toward the facility. Therefore, this study aims to see the relationship between service quality and treatment decisions and patient loyalty at Mampang Prapatan Hospital. 


\section{LITERATURE REVIEW}

Consumer loyalty is defined as a measure of customer loyalty in using a product brand or service brand over a certain period of time in a situation where there are many choices of products or services that can meet their needs and customers have the ability to get them (Saladin, 2006). There are six indicators that can be used to measure patient loyalty, namely :(Setiawan, 2011):

1) Repeat purchase,

2) The habit of consuming the brand,

3) Always liked the brand,

4) Keep choosing the brand, and believe that the brand is the best, and

5) Recommend the brand to others

Decision making can be defined as the process of making choices from various alternatives (Fandy, 2007). Therefore, treatment decisions are made based on general decision-making considerations. Where patients as consumers of hospital services find out/identify what they need after that search for information about where they will get services according to their needs and desires and carry out alternative assessments based on branding (how a facility is known in the community) and based on criteria and capabilities (high and low price to be paid, as well as other criteria according to the patient's condition) (Francesco \& Gold, 2005).

Service quality is an effort to meet the wants and desires of customers, as well as delivery accuracy in order to maintain a balance between customer expectations (Kanuk, 2008). The main dimensions that are the major factors in determining service quality are as follows: (Irmawati \& Kurniasari, 2012):

1) Reliability, namely the ability to deliver the promised service reliably and accurately.

2) Responsiveness, namely the willingness to help consumers by providing fast and appropriate service.

3) Assurance, that includes knowledge, ability, and courtesy or kindness of the person as well as the ability to gain trust and desire.

4) Empathy, that includes maintaining and providing a level of individual or personal attention to consumer needs.

5) Tangible (Direct evidence), that includes physical facilities, equipment or supplies, prices, and personal appearance and written materials.

\section{RESEARCH METHOD}

This study is a quantitative study which uses Structural Equation Modeling analysis using the lisrel application to see the relationship between variables. This study utilizes 148 respondents from all outpatients at Mampang Prapatan Hospital from March to May 2018. 


\section{RESULT AND DISCUSSION}

\subsection{Result Research}

Table 1 Distribution of Respondents

\begin{tabular}{|c|c|c|}
\hline No. & Amount & Percentage $(\%)$ \\
\hline \multicolumn{3}{|l|}{ Gender } \\
\hline Man & 60 & 40.5 \\
\hline Woman & 88 & 59.5 \\
\hline \multicolumn{3}{|l|}{ Age } \\
\hline $0-16$ & 12 & 8.1 \\
\hline $17-24$ & 26 & 17.6 \\
\hline $25-34$ & 48 & 32.4 \\
\hline $35-49$ & 37 & 25.0 \\
\hline$>50$ & 25 & 16.9 \\
\hline \multicolumn{3}{|l|}{ Clinic Visited } \\
\hline Emergency room (IGD) & 39 & 26.4 \\
\hline Internal disease & 38 & 25.7 \\
\hline Content & 29 & 19.6 \\
\hline Nerves & 15 & 10.1 \\
\hline Child & 14 & 9.5 \\
\hline ENT & 8 & 6.1 \\
\hline Lungs & 3 & 2.0 \\
\hline Tooth & 1 & 0.7 \\
\hline \multicolumn{3}{|l|}{ Occupation } \\
\hline Student & 14 & 9.5 \\
\hline Civil Servant & 10 & 6.8 \\
\hline Private & 39 & 26.4 \\
\hline Etc. & 85 & 57.4 \\
\hline \multicolumn{3}{|l|}{ Income } \\
\hline$<3$ million & 92 & 62.2 \\
\hline $3-7$ million & 48 & 32.4 \\
\hline$>7$ million & 8 & 5.4 \\
\hline \multicolumn{3}{|l|}{ Cost Bearer } \\
\hline Personal & 61 & 41.2 \\
\hline BPJS/KIS & 85 & 57.4 \\
\hline Other Insurance & 2 & 1.4 \\
\hline Total & 148 & 100 \\
\hline
\end{tabular}




\subsubsection{The Results of Service Quality Analysis on Loyalty through Treatment}

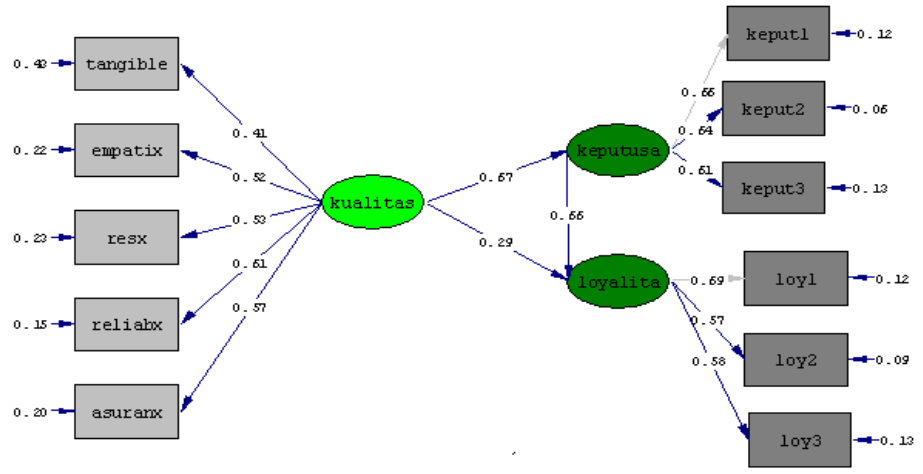

\section{Decisions}

Figure 1 Path Test Results

The direction of the direct influence of service quality on patient loyalty has a coefficient value of $r=0,6(t$ value $=7.99$, significance $>1,96)$. Meanwhile, the direction of indirect influence of service quality on patient loyalty through treatment decisions has a coefficient value of $r=0.66 \times 0.29=0,1914$ ( $t$ value 4,83 ).

\subsubsection{The Results of Service Quality Analysis on Treatment Decisions through Patient} Loyalty

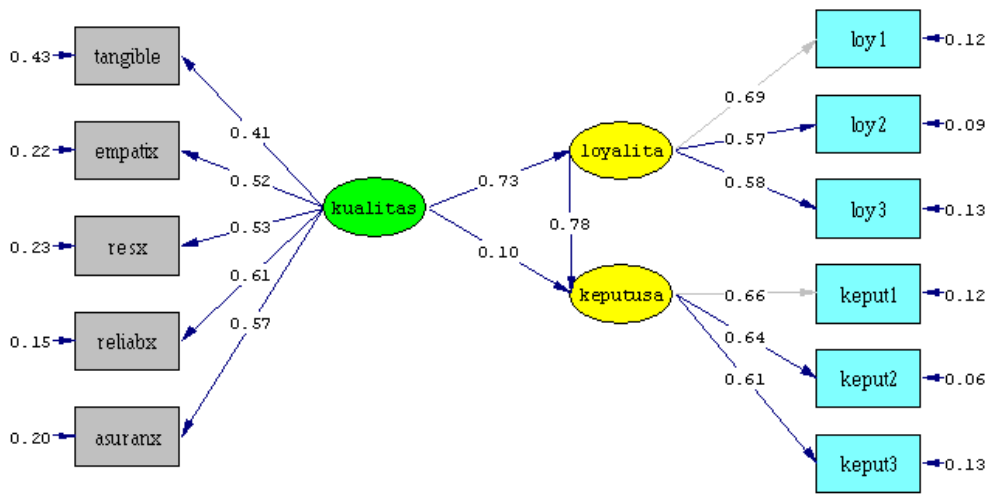

Figure 2 Path Test Results

The direction of direct influence of service quality on treatment decisions has a coefficient value of $r=0.73$ ( $t$ value $=5,64$ significance $>1,96)$. Meanwhile, the direction of the indirect influence of service quality on treatment decisions through patient loyalty has a coefficient value of $r=0.78 \times 0.1=0,078$ ( $t$ value 5,18$)$. 


\section{JOURNAL OF MANAGEMENT, ACCOUNTING, GENERAL FINANCE AND INTERNATIONAL ECONOMIC ISSUES \\ (MARGINAL) \\ VOLUME 1 ISSUE 2 (2022)}

\subsection{Discussion}

In this study, it was concluded that service quality has a significant influence on treatment decisions. The results of a study on service quality with the patient's decision to seek treatment stated that the quality of service simultaneously influenced the place and price on patient satisfaction which was the background for the decision to seek treatment at Moewardi Hospital where the research was conducted (Irmawati \& Kurniasari, 2012).

Another study was conducted by analyzing the quality of service associated with customer/patient satisfaction. Where patient satisfaction is widely associated with patient treatment decisions. This can be input for further research to analyze further by linking it with patient satisfaction as a variable between service quality and treatment decisions.

In this study, it was concluded that service quality had a significant influence on treatment decisions. This is similar to a study entitled The Effect of Service Quality on Patient Loyalty at Meloy Hospital in Sangatta, which states that tangible, reliable, responsiveness, assurance, and empathy (service quality) simultaneously have a significant effect on patient loyalty (Dewi, 2017).

Furthermore, the study entitled Analysis of Patient Loyalty and Service Quality at the Orthodontic Polyclinic of Dr Hasan Sadikin hospital, Bandung, to find out the dimensions of service quality have a significant effect on patient loyalty. This study, aims to find out which dimension has the most influence on patient loyalty, and it was found that the assurance dimension has a dominant influence compared to other dimensions of service quality (SK Raden, 2010).

This is similar to the research entitled The Effect of Service Quality on Patient Loyalty of BPJS Users with Patient Satisfaction which states that service quality has a positive and significant effect on patient loyalty (Dewi, 2017).

\section{CONCLUSION}

To sum up everything that has been stated so far, the following conclusions can be drawn in this study, namely:

1. There is a significant effect of Tangible, Reliability, Responsiveness and Assurance Dimensions on Service Quality, while the Empathy dimension has no significant effect on Service Quality.

2. There is a significant effect of Service Quality Variables on Patient Loyalty.

3. There is a significant effect of Service Quality Variables on Patient Loyalty through the Treatment Decision variable.

4. There is a significant effect of Service Quality on Treatment Decisions.

5. There is a significant effect of Service Quality on Treatment Decisions through Patient Loyalty.

\section{REFERENCES}

Dewi, R. (2017). Pengaruh kualitas pelayanan terhadap loyalitas pasien pengguna BPJS dengan kepuasan pasien sebagai variabel intervening. Jurnal Manajemen Dayasaing, $18(2), 146-156$.

Fandy, T. (2007). Strategi Pemasaran, edisi kedua. Yogyakarta: Penerbit Andi. 
Francesco, A. M., \& Gold, B. A. (2005). International organizational behavior.

Irmawati, I., \& Kurniasari, R. (2012). Pengaruh kualitas pelayanan jasa terhadap keputusan pasien berobat rawat inap di RSUD Moewardi Jebres. Benefit: Jurnal Manajemen Dan Bisnis, 15(1), 27-52.

Kanuk, S. (2008). Leon \&, Leslie Lazar,“Consumer Behaviour” 7th Edition (Perilaku Konsumen), PT. Indeks, Jakarta, 4(1), 25-35.

Kotler, P., \& Armstrong, G. (2001). Manajemen Pemasaran: Analisis, Perencanaan, Implementasi, dan Kontrol. jakarta: PT Prehallindo.

Ristrini, R. (2005). Perubahan paradigma jasa pelayanan kesehatan rumah sakit dan rekomendasi kebijakan strategis bagi pimpinan. Jurnal Manajemen Pelayanan Kesehatan, $8(01)$.

Saladin, D. (2006). Manajemen pemasaran. Edisi Keempat, Bandung: Linda Karya.

Setiawan, S. (2011). Loyalitas pelanggan jasa. PT Penerbit IPB Press.

SK Raden, C. (2010). Analisis Loyalitas dan Kualitas Layanan di Poliklinik Ortonsi RSUD. DR. Hasan Sadikin Bandung. Tesis: Universitas Indonesia FKM Program Pascasarjana Peminatan Manajemen Pelayanan Kesehatan. 